\title{
The reinforced full-root technique for the Ross operation: surgical considerations and operative insights
}

\author{
Markus Liebrich ${ }^{1}$, Efstratios I. Charitos ${ }^{2}$, Christoph Dingemann ${ }^{1}$, Detlef Roser ${ }^{1}$, Joerg Seeburger ${ }^{1}$, \\ Wolfgang Hemmer ${ }^{1}$, Vladimir Voth ${ }^{1}$
}

${ }^{1}$ Sana Cardiac Surgery Stuttgart, Stuttgart, Germany; ${ }^{2}$ Department of Cardiac Surgery, University of Bonn, Medical School, Bonn, Germany

Correspondence to: Markus Liebrich, MD. Sana Cardiac Surgery, Herdweg 2, 70174 Stuttgart, Germany. Email: Markus.Liebrich@sana.de.

\begin{abstract}
Background: Surgical treatment of young and middle-aged patients suffering from aortic valve disease remains an unresolved issue due to the limited durability of bioprosthetic heart valve replacements and the valve-related morbidity of patients with mechanical valve substitutes. Theoretically, the "living valve" principle of the Ross operation may represent a potentially viable solution to this dilemma. In this paper, we report on the surgical techniques of the Ross procedure and present long-term post-operative outcomes using the reinforced full-root technique.

Methods: From 1995 to 2020, a total of 832 consecutive patients (mean age, 43.4 13.7 years; 617 males) underwent a Ross operation using the full-root technique. Patients were prospectively monitored with clinical and echocardiographic follow-up. Total follow-up was 9,046 patients-years and was 92\% complete. Mean-follow-up was $10.9 \pm 6.9$ years (range, $0-24.9$ years)

Results: Survival at twenty years was 92\% (95\% CI: 90-94\%). Freedom from autograft or right ventricle to pulmonary artery connection reoperation at twenty years was 79\% (95\% CI: 74-85\%). Eighty-nine pulmonary autograft reoperations had to be performed in eighty patients; salvage of the pulmonary autograft could be performed in forty-six of them. Fifty-seven patients required sixty-three reoperations on the right ventricle to pulmonary artery connection. Major cerebral bleeding occurred in one patient and neurological events in seventeen patients, respectively.

Conclusions: Over a follow-up interval of up to twenty-five years, the Ross operation with the reinforced full-root technique demonstrated excellent survival in young and middle-aged patients. The rate of pulmonary autograft and right ventricular outflow graft reoperations were low in this patient subset. Therefore, the Ross operation with the reinforced full-root technique represents an enduring and valid treatment option in young and middle-aged patients suffering from aortic valve disease.
\end{abstract}

Keywords: Ross operation; surgical technique; follow-up

Submitted Oct 15, 2020. Accepted for publication May 12, 2021.

doi: $10.21037 /$ acs-2020-rp-22

View this article at: https://dx.doi.org/10.21037/acs-2020-rp-22

\section{Introduction}

Surgical treatment of aortic valve (AV) disease has dramatically changed in the last two decades, particularly since the introduction of transcatheter guided AV-therapy (1). However, young and middle-aged patients requiring $\mathrm{AV}$ replacement are still confronted with a treatment dilemma: although mechanical valves bear the risk of thromboembolic and bleeding events, bioprosthetic substitutes have limited durability (2). Nevertheless, emerging technologies in alternative surgical treatment strategies in AV disease have not yet become an armamentarium with acceptable enduring long-term results (3-6). This includes advancements such as new generations of bioprosthetic substitutes with anticipated improved long-term durability, innovative mechanical prosthesis design with reduced need for anti-coagulation, decellularized allografts with the theoretical potential to overcome the high early failure 


\begin{tabular}{|ll}
\hline \multicolumn{2}{|l}{ Table 1 Baseline characteristics and preoperative data } \\
\hline Characteristics & Value \\
\hline Patients, $n$ [\%] & $832[100]$ \\
\hline Gender, $n$ [\%] & \\
\hline Male & $617[74]$ \\
\hline Female & $215[26]$ \\
\hline Age, mean \pm SD, years & $43.4 \pm 13.7$ \\
\hline Ejection fraction, $n$ [\%] & \\
\hline$>50 \%$ & $480[89]$ \\
\hline $30 \%$ to 50\% & $57[11]$ \\
\hline$<30 \%$ & $5[1]$ \\
\hline Arterial hypertension, $n$ [\%] & $235[28]$ \\
\hline AV-hemodynamics, $n$ [\%] & \\
\hline AV-stenosis & $264[32]$ \\
\hline AV-regurgitation & $153[18]$ \\
\hline Combined AV-lesion & $414[50]$ \\
\hline AV, aortic valve; SD, standard deviation. & \\
\hline
\end{tabular}

rate of conventional $\mathrm{AV}$ prostheses due to minimized immunogenicity, and last but not least, the introduction of reconstructive procedures such as the Ozaki method. Taking these advancements into consideration, the Ross operation can play a central role with its numerous advantages (7). The Ross operation was initially performed as a subcoronary transplant, and further popularized with invention of the full-root technique (FRT). After the emergence of midterm data suggesting unexpectedly elevated reoperation rates, utilization of the Ross operation was reduced (8). Remarkably, several working groups recently reported excellent long-term outcomes and low rates of reintervention following the Ross operation (9). Nonetheless, current guidelines recommend either a conservative approach or to disregard the Ross operation as an alternative treatment option $(10,11)$. Although, long-term evidence in support of the original subcoronary technique is increasing, significant data in support of the reinforced FRT is relatively rare (12). Therefore, we report selected results from over 800 patients who have received the Ross operation with the reinforced FRT, encompassing a follow-up of twenty-five years. To date, this appears to reflect one of the largest studies of this kind reported in the literature.

\section{Methods}

\section{Patient characteristics}

Between February 1995 and June 2020, a Ross operation was performed in 832 patients at our institution. Baseline characteristics are displayed in Table 1. Indications for a Ross operation were AV stenosis (264 patients, 32\%), AV regurgitation (154 patients, 19\%), and a mixed AV lesion (414 patients, $50 \%$ ) in combination with the patient's request to eliminate oral anti-coagulation, a sportive lifestyle, women in childbearing years, or a contraindication to oral anticoagulation. Contraindications for a Ross operation included greater than two-vessel coronary artery disease, connective tissue disorders or a history of rheumatic disease, severely reduced left ventricular function, significant anomalies of the pulmonary valve or a shortened life expectancy due to other explanations. The indications were in line with the current guidelines of the American Heart Association and European Society of Cardiology $(10,11)$.

\section{Operative technique}

All patients included in this retrospective study were operated on with the FRT. A "freestanding aortic root replacement" without autograft reinforcement (AR) was performed in 224 patients, 27\% (FRT) or with AR in 608 patients, 73\% (FRT + AR). For right ventricle to pulmonary artery (RV$\mathrm{PA})$ reconstruction, mostly a cryopreserved homograft ( $n=768,92 \%)$ was implanted. The operative technique of the reinforced FRT is demonstrated in detail in Video 1. Concisely stated, a standard cardiopulmonary bypass with bi-caval cannulation and mild hypothermia $\left(34^{\circ} \mathrm{C}\right)$ are performed in all patients. Cold blood cardioplegia (Buckberg-Solution, B. Braun, Melsungen, Germany) at twenty-minute intervals has been administered to induce and maintain cardiac arrest. After inspection of the $\mathrm{AV}$, the main pulmonary artery is transected, inspected and assessed to be morphologically absolutely normal for usage as a pulmonary autograft. Once the autograft is prepared, it is trimmed, leaving only a 3-4-mm rim of muscular tissue (Video 1, sequence: preparation of the autograft). Subsequently, the AV is excised, the aortic root and both right and left -coronary buttons are mobilized. The autograft is sized using a Hegar dilator. Following this, three Prolene polypropylene sutures are equally placed into the native aortic annulus in each nadir and passed through the corresponding nadirs of the pulmonary autograft. Finally, the pulmonary autograft is fixed with the three Prolene polypropylene sutures 


\begin{tabular}{ll} 
Table 2 Intraoperative data \\
\hline Variable & Value \\
\hline CPB-time, mean \pm SD, min & $172.0 \pm 40.2$ \\
\hline X-clamp-time, mean \pm SD, min & $137.0 \pm 25.5$ \\
\hline CPB, cardiopulmonary bypass; SD, standard deviation.
\end{tabular}

to the native aortic annulus with ties. The proximal autograft anastomosis is performed using a running suture technique from one nadir to the other and then tied. In the FRT + AR group, a Dacron strip is incorporated in the proximal suture line, and a second suture line is fixed from the aortic wall remnant to the autograft to stabilize the native aortic annulus, thereby preventing consecutive autograft dilatation (Video 1, sequence: sewing of the autograft). The coronary ostia are also re-implanted into the autograft with a continuous suture technique (5/0 Prolene polypropylene; Video 1, sequence: reimplantation of the left-/and right-coronary arteries). The RVPA connection is implanted proximally and distally using $4 / 0$ and 5/0 Prolene polypropylene continuous sutures, respectively (Video 1, sequence: completion and manufacturing of the proximal and distal homograft anastomosis). The ascending aorta is replaced or sewn to the autograft (Video 1, sequence: suturing of the aorta-autograft anastomosis). Intra-operative data are shown in Table 2.

\section{Follow-up}

The study was approved by the local ethics committee (University of Tuebingen, Medical School; Clinical Trials ID: 484/2020BO). Follow-up was performed as outpatients on an annual basis using standard clinical examination, evaluation and transthoracic echocardiography. Peri- and post-operative events were registered according to the guidelines for reporting mortality and morbidity after cardiac valve interventions (13). The median follow-up time was $10.9 \pm 6.9$ years (range, $0-24.9$ years); total followup comprised 9,046 patients-years, with completeness of follow-up at $92 \%$. Mean follow-up was $10.9 \pm 6.9$ years.

\section{Statistical analysis}

Descriptive variables are presented as the mean \pm standard deviation (SD) and categorical variables as absolute and relative frequencies. The time-to-event outcomes were analyzed using survival methods (Kaplan-Meier).
Statistical analyzes were performed using $\mathrm{R}$ version 4.0.2 (R Development Core Team 2020; Vienna, Austria). The statistical significance level of $\mathrm{P}$ value $<0.05$ was used.

\section{Results}

\section{Patients' survival}

No intra-operative death occurred. thirty-day mortality was $0.96 \%(\mathrm{n}=8)$ due to myocardial infarction in three patients; multi-organ failure, right ventricular failure, hepatorenal syndrome, sudden death, and arrhythmia ( $\mathrm{n}=1$, respectively). Peri-operative data is given in Table 3. There were fiftytwo late deaths (>30 days). A cardiac-related death occurred in fifteen patients, resulting in a linearized ration of $1.4 \% /$ patient-year. The overall cumulative survival was $97 \%$ (95\% CI: $95-98 \%$ ) at five years, $92 \%$ (95\% CI: 90-94\%) at fifteen years, $86 \%$ (95\% CI: 82-90\%) at 20 years (Figure 1).

\section{Ross-related reoperations}

One hundred and thirty-seven patients required a Rossrelated reoperation during 9,046 patient-years of followup (Figure 2). The median time to first reoperation was 8.2 years, while reoperative hospital mortality was $1.1 \%$.

\section{Morbidity}

\section{Stroke, thromboembolism, and bleeding events}

Eleven patients suffered a transient ischemic attack (0.15\%/ patient-year), while the stroke rate was $0.7 \% /$ patient-year. A valve-related thromboembolism and major bleeding were evident in one patient $(0.01 \%$ /patient-year), respectively.

\section{Postoperative echocardiographic and functional condition}

Table 3 displays echocardiographic characteristics of the pulmonary autograft and RV-PA connection.

\section{Discussion}

The main objective of this study was to demonstrate surgical technique and present an overview of long-term data after the Ross operation using the reinforced FRT.

\section{Major pitfalls}

(I) Injury to the left main coronary artery and to the first septal coronary artery due to its proximity to the 


\begin{tabular}{ll} 
Table 3 Perioperative data & \\
\hline Variable & $\mathrm{N}(\%)$ \\
\hline Early mortality (<30 days) & $8(0.9)$ \\
\hline Reoperation for bleeding & $37(4.4)$ \\
\hline Myocardial infarction & $11(1.3)$ \\
\hline Procedure-related CABG & $15(1.8)$ \\
\hline CABG, coronary artery bypass graft. & \\
\hline
\end{tabular}

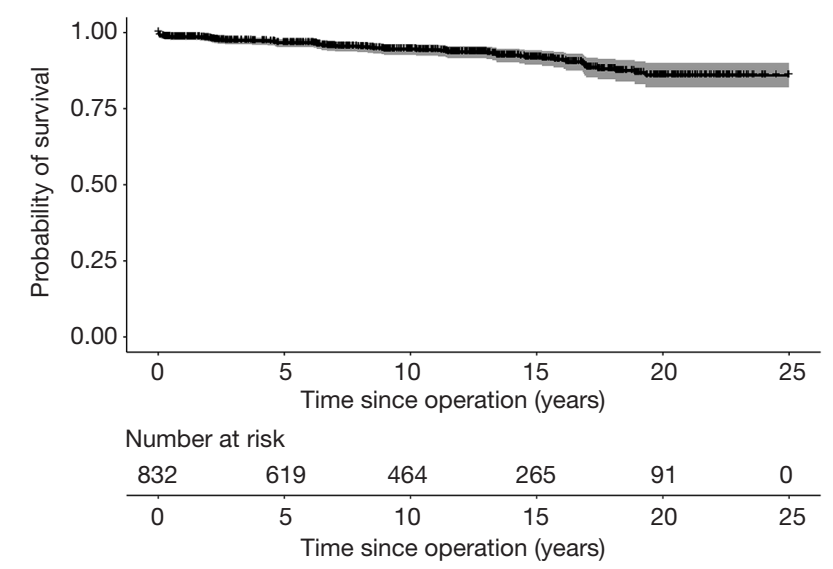

Figure 1 Survival probability of Ross patients operated on with the reinforced full-root technique. Patients at risk are also demonstrated.

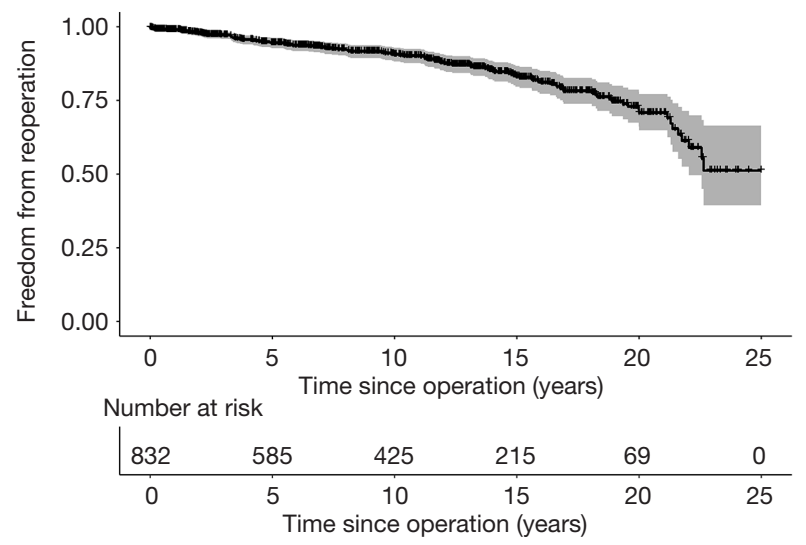

Figure 2 Actuarial estimates of freedom from autograft or RVPA connection reoperation. Patients at risk and the estimated probabilities (with $95 \%$ confidence intervals) are presented. RV$\mathrm{PA}$, right ventricle to pulmonary artery. pulmonary valve and root. Dissection of the autograft must be performed with utmost care by incising the endocardium on the posterior right ventricular outflow tract with a \#15 blade, approximately 5-8 mm below the pulmonary valve annulus.

(II) Autograft leaflet damage by avoiding deep stitching during the proximal "reinforced" suture line, especially when performing the second suture line for definite stabilization of the neo-aortic annulus.

(III) Kinking of the RV-PA connection, leaving the RV-PA connection too long in comparison to the pulmonary autograft, which may result in kinking of the distal suture line when the heart is filled with blood.

\section{Caution}

(I) Autograft dilatation can be avoided by reinforcement of the proximal autograft anastomosis, keeping the autograft short in length, as well as distal autograft stabilization (neo-sinotubular junction) by generous replacement of the ascending aorta with a Dacron tube.

(II) Autograft regurgitation, by sewing of the autograft to the native aortic annulus without malalignment or distortion, and a slight "oversizing" of the autograft by $2-3 \mathrm{~mm}$, if anatomically inevitable by commissural plication of the coronary sinus.

(III) Bleeding from the muscular autograft bed can be identified and controlled by retrograde perfusion through the coronary sinus, which identifies small bleeding vessels that would otherwise have remained unnoticed. Hemostasis at this stage of the operation can be accomplished easily and effectively with lowcurrent electrocautery.

\section{Survival}

This series showed an excellent survival rate as late as twenty-five years following the Ross operation. This is noteworthy, as the study population, with a mean age of forty-three years, represents the "young and middleaged" patient population facing this notorious treatment dilemma (2). Independent of the type of AV replacement (bioprosthetic or mechanical valves) implanted in young adults, poorer outcomes compared to Ross operation patients and a substantially lower life expectancy than the general population could be demonstrated (14). 


\section{Ross-related reoperation}

The risk of reoperation after the Ross operation remains a matter of concern $(15,16)$. A statistically significant incidence of progressive neo-aortic root dilatation has been reported when using the full-root technique (8). In the present study, freedom from autograft or RV-PA connection reoperation was extremely low and comparable with long-term results published for the subcoronary transplant technique (9). In $52 \%$ of autograft reoperations, the patients' former pulmonary valve could be spared, mostly by the David procedure (17).

\section{Limitations}

This work consists of the known shortcomings of a retrospective, observational investigation. Clinical and echocardiographic data were obtained on a prospective follow-up basis with an incomplete follow-up due to crossregional patient distribution. In addition, patients receiving a Ross operation represent a pre-selected population, thus making it difficult to compare with alternative AV substitutes.

\section{Conclusions}

The Ross operation with the reinforced full-root technique is a technically challenging but feasible procedure in experienced and high-volume centres. If performed in this setting, the presented operative technique shows low morbidity and mortality as well as excellent long-term results with respect to freedom from autograft and RV-PA connection reoperation and survival, even twenty-five years after the index operation.

\section{Acknowledgments}

We thank Bianca Enderlin for her help with data acquisition.

Funding: None.

\section{Footnote}

Conflicts of Interest: The authors have no conflicts of interest to declare.

Open Access Statement: This is an Open Access article distributed in accordance with the Creative Commons Attribution-NonCommercial-NoDerivs 4.0 International License (CC BY-NC-ND 4.0), which permits the non- commercial replication and distribution of the article with the strict proviso that no changes or edits are made and the original work is properly cited (including links to both the formal publication through the relevant DOI and the license). See: https://creativecommons.org/licenses/by-nc-nd/4.0/.

\section{References}

1. Mack MJ, Leon MB, Thourani VH, et al. Transcatheter Aortic-Valve Replacement with a Balloon-Expandable Valve in Low-Risk Patients. N Engl J Med 2019;380:1695-705.

2. Puvimanasinghe JP, Takkenberg JJ, Edwards MB, et al. Comparison of outcomes after aortic valve replacement with a mechanical valve or a bioprosthesis using microsimulation. Heart 2004;90:1172-8.

3. Puskas JD, Bavaria JE, Svensson LG, et al. The COMMENCE trial: 2-year outcomes with an aortic bioprosthesis with RESILIA tissue. Eur J Cardiothorac Surg 2017;52:432-9.

4. Puskas JD, Gerdisch M, Nichols D, et al. Anticoagulation and Antiplatelet Strategies After On-X Mechanical Aortic Valve Replacement. J Am Coll Cardiol 2018;71:2717-26.

5. Horke A, Tudorache I, Laufer G, et al. Early results from a prospective, single-arm European trial on decellularized allografts for aortic valve replacement: the ARISE study and ARISE Registry data. Eur J Cardiothorac Surg 2020;58:1045-53.

6. Ozaki S, Kawase I, Yamashita H, et al. Midterm outcomes after aortic valve neocuspidization with glutaraldehydetreated autologous pericardium. J Thorac Cardiovasc Surg 2018;155:2379-87.

7. Weimar T, Charitos EI, Liebrich M, et al. Quo vadis pulmonary autograft--the ross procedure in its second decade: a single-center experience in 645 patients. Ann Thorac Surg 2014;97:167-74.

8. Klieverik LM, Takkenberg JJ, Bekkers JA, et al. The Ross operation: a Trojan horse? Eur Heart J 2007;28:19932000.

9. Sievers HH, Stierle U, Petersen M, et al. Valve performance classification in 630 subcoronary Ross patients over 22 years. J Thorac Cardiovasc Surg 2018;156:79-86.e2.

10. Nishimura RA, Otto CM, Bonow RO, et al. 2014 AHA/ ACC guideline for the management of patients with valvular heart disease: a report of the American College of Cardiology/American Heart Association Task Force on 
Practice Guidelines [published correction appears in J Am Coll Cardiol. 2014 Jun 10;63(22):2489. Dosage error in article text]. J Am Coll Cardiol 2014;63:e57-185.

11. Baumgartner H, Falk V, Bax JJ, et al. 2017 ESC/EACTS Guidelines for the management of valvular heart disease. Eur Heart J 2017;38:2739-91.

12. Charitos EI, Stierle U, Hanke T, et al. Long-term results of 203 young and middle-aged patients with more than 10 years of follow-up after the original subcoronary Ross operation. Ann Thorac Surg 2012;93:495-502.

13. Akins CW, Miller DC, Turina MI, et al. Guidelines for reporting mortality and morbidity after cardiac valve interventions. Ann Thorac Surg 2008;85:1490-5.

14. van Geldorp MW, Eric Jamieson WR, Kappetein AP, et al. Patient outcome after aortic valve replacement with

Cite this article as: Liebrich $M$, Charitos EI, Dingemann C, Roser D, Seeburger J, Hemmer W, Voth V. The reinforced fullroot technique for the Ross operation: surgical considerations and operative insights. Ann Cardiothorac Surg 2021;10(4):485490. doi: 10.21037/acs-2020-rp-22 a mechanical or biological prosthesis: weighing lifetime anticoagulant-related event risk against reoperation risk. J Thorac Cardiovasc Surg 2009;137:881-6, 886e1-5.

15. Richardt D, Hemmer W, Moritz A, et al. Age-related reoperation rate after the Ross procedure: a report from the German Ross Registry. J Heart Valve Dis 2015;24:220-7.

16. Charitos EI, Takkenberg JJ, Hanke T, et al. Reoperations on the pulmonary autograft and pulmonary homograft after the Ross procedure: An update on the German Dutch Ross Registry. J Thorac Cardiovasc Surg 2012;144:813-21; discussion 821-3.

17. Liebrich M, Weimar T, Tzanavaros I, et al. The David procedure for salvage of a failing autograft after the Ross operation. Ann Thorac Surg 2014;98:2046-52. 